\title{
Erratum: RENATA study-Latin American prospective experience: clinical outcome of patients treated with palbociclib in hormone receptor-positive metastatic breast cancer-real-world use
}

\author{
Fernando Petracci ${ }^{1}$, Gonzalo Gomez Abuin², Alejandra Pini ${ }^{3}$ and Matías Chacón ${ }^{4}$ \\ ecancer 141058 (2020) https://doi.org/10.3332/ecancer.2020.1058 \\ ${ }^{1}$ Breast Cancer Department, Instituto Alexander Fleming and Sanatorio Las Lomas, Buenos Aires 1428, Argentina \\ ${ }^{2}$ Oncology Service, Hospital Alemán, Buenos Aires 1428, Argentina \\ ${ }^{3}$ Oncology Service, Hospital Militar Central and Sanatorio Las Lomas, Buenos Aires 1428, Argentina \\ ${ }^{4}$ Oncology Service Chair, Instituto Alexander Fleming, Buenos Aires 1642, Argentina
}

Keywords: hormone receptor-positive, advanced breast cancer, Palbociclib, real-world, progression-free survival, overall survival

On page 3, the number 72.5 in the following sentence replaces the number 37.5 which was incorrect:

'The Overall CB was $82.5 \%$, higher in first line than in second line, $85.9 \%$ and $62.5 \%$, respectively. The ORR in first line were: 4.7\% CR, 40.6\% PR and 40.6\% SD. In second line the ORR were: $25 \%$ PR, $37.5 \%$ SD and no CR.'

\section{Conflicts of interest}

There are no conflicts of interest.

\section{Funding statement}

This research did not receive any specific grant from funding agencies in the public, commercial or not-for-profit sectors.
Correspondence to: Fernando Petracci

Email: fpetracci@yahoo.com

ecancer 2020, 14:1087

https://doi.org/10.3332/ecancer.2020.1087

Published: 07/08/2020

Received: 21/07/2020

Publication costs for this article were supported by ecancer (UK Charity number 1176307).

Copyright: (c) the authors; licensee ecancermedicalscience. This is an Open Access article distributed under the terms of the Creative Commons Attribution License (http:// creativecommons.org/licenses/by/3.0), which permits unrestricted use, distribution, and reproduction in any medium, provided the original work is properly cited. 